\title{
Stadig værre udsigter for Afghanistan
}

\section{Samina Ahmed}

\section{Sikkerhedssituationen forværres i takt med, at den udenlandske tilbagetrækning nærmer sig. Og pa- kistansk militærs støtte til oprørere slutter først, når USA lægger stærkt nok pres på Pakistan}

Med de internationale styrkers overdragelse af ansvaret på slagmarken til deres afghanske partnere før udgangen af 2013 fulgt af deres tilbagetrækning i 2014 går Afghanistan ind i en afgørende periode. Overgangen, der allerede er godt i gang, finder sted i en tid, hvor sikkerheden er forværret over hele landet. Antallet af civile dødsofre stiger, for oprør har bredt sig til tidligere relativt sikre områder bl.a. i de nordlige og centrale regioner. Men også det forhold, at Kabul udsættes for massive angreb, varsler ilde for Afghanistans stabilitet, da de Afghanske Nationale Sikkerhedsstyrker (ANSF) ikke er klar til at overtage ansvaret for sikkerheden, end ikke i 2014.

1. maj 2012 underskrev præsidenterne Barack Obama og Hamid Karzai en 'Enduring Partnership Agreement', hvori USA forpligter sig til at "konsolidere et varigt partnerskab med Afghanistan, der styrker afghansk suverænitet, stabilitet og velstand samt bidrager til vores fælles mål at slå al-Qaeda og dets ekstremistiske allierede tilbage" (The U.S.Afghanistan Strategic Partnership Agrement, Det Hvide Hus 1. maj 2012). 21. maj forpligtede NATOs ledere sig til 4,1 milliarder dollar i årlig assistance til ANSF, mens Afghanistan gradvist overtager det finansielle ansvar i løbet af det næste årti. På donorkonferencen i Tokyo i juli 2012 lovede donorlandene at give Afghanistan 16 milliarder dollar i civil bistand til og med 2015. USA har også givet Kabul status som 'større ikke-Nato allieret' som signal om fortsat støtte i håbet om, at Afghanistan forbliver stabilt efter tilbagetrækningen.

Disse forpligtelser sender som et 
minimum et signal til afghanerne om, at det internationale samfund har til hensigt at afslutte krigen, men ikke vil forhaste sin afgang. Det er også et signal til Afghanistans naboer især Pakistan, om at internationale, især amerikanske, styrker vil blive i Afghanistan efter 2014 om end i mindre antal, så deres islamistiske håndlangere ikke nødvendigvis kan vinde magt med våben. Det er også en besked til oprørerne om, at deres sejr ikke nødvendigvis er lige om hjørnet. Men 2014-overgangen ændrer faktisk forholdene i landet. Understregningen af en slutdato for de udenlandske styrkers tilstedeværelse og overdragelse af sikkerhedsledelsen til ANSF endnu før 2014 har givet oprørerne blod på tanden.

Oprørets nuværende stade er et oplagt udgangspunkt for at vurdere krigens og konfliktens karakter i Afghanistan.

\section{Oprørets kapacitet}

Det er blevet hævdet, at den pludselige store forøgelse af de amerikanske styrker ('the surge') skulle have bidraget til at stabilisere de hårdest konfliktramte regioner, især i det sydlige og østlige Afghanistan, men herimod taler større sikkerhedsudfordringer forude for Kabul og dets internationale partnere. Efter tilbagetrækningen af de 33.000 tilførte mand, er den amerikanske militære tilstedeværelse reduceret fra 100.000 i 2011 til 68.000 i oktober 2012.
ISAF ventes at reducere til lidt under 100.000 i slutningen af 2012 fra 150.000 i 2011. Mange af de deltagende landes tropper vil forlade landet længe før exitdagen i 2014.

Frankrig vil trække sine 3.400 soldater tilbage $i$ år og har allerede overdraget Kapisa til ANSF. New Zealand har besluttet at trække sine tilbage i april 2013 efter drabene på fem af dets soldater i august 2012. De trækkes tilbage fra Badakhshan, en af de fredeligste provinser og en af de første, der blev overdraget til ANSF's ledelse. Det skete i juli 2011.

Mens krigen i Afghanistan går ind i sit tolvte år, forværres sikkerheden fortsat på landsplan, hvor opstanden er udvidet langt ud over Talebans hidtil vigtigste bastioner i det sydlige og østlige Afghanistan. Der er flere drab på civile end nogensinde før, og angreb, herunder selvmordsbombninger, finder sted i regioner, hvor Taleban først er dukket op for nylig, som fx de nordlige provinser Kunduz og Nimroz. Taleban har i mange regioner rundt i landet skabt skyggeregeringer, der nyder godt af centralregeringens korruption og manglende evne til at vinde opbakning.

I takt med at overgangen nærmer sig, er oprørsstrategier ændret fra tidligere års storstilede angreb til udbredt anvendelse af vejsidebomber og selvmordsangreb på afghanske sikkerhedsstyrker og deres internationale allierede. Siden krigen begyndte er 3200 Nato soldater dræbt, 
heraf over 2000 amerikanere.

Som et led i psykologisk krigsførelse har oprørerne i stigende grad begået 'insider'-angreb, hvor de har brugt sympatisører i ANSF til at ramme udenlandske styrker. Intensiveringen af 'grønne mod blå' angreb tager sigte på at skabe mistillid imellem ANSF og deres udenlandske partnere, påvirke den vestlige opinion og skabe indtryk af, at afghanske magthavere stadig holder sig på sidelinjerne. Indtil nu har der være mindst 52 drab (næsten halvdelen på amerikanere) under sådanne angreb i 2012. Det drejer sig om en ud af fem døde i kamp blandt NATOs styrker. Som resultat af disse angreb er nogle fællesoperationer blevet begrænset.

Taleban understreger, at det har ændret fokus for operationerne 'til at ramme fjenden på dens egne baser'. General Martin Dempsey, USA's generalstabschef, har kaldt disse angreb en meget alvorlig trussel imod krigsindsatsen. NATOs generalsekretær, Anders Fogh Rasmussen, har sagt: "Man kan roligt sige, at en afgørende del af insider-angrebene skyldes Talebans taktik. ... De indgår sandsynligvis i Talebans i strategi". Han tilføjede: "Der er ingen tvivl om, at insider angrebene har undergravet tilliden". (The Guardian, den 1. oktober 2012).

Insider-angreb rettes også imod ANSF. I 2012 har afghanske soldater og politifolk dræbt over 50 af deres kolleger. Mens den afghanske rege- ring tidligere har beskyldt 'udenlandske spioner' for angrebene, er den begyndt at iværksætte planer om påny at gennemgå listerne for personel.

Selv om oprørerne er ansvarlige for 80 pct. af den store stigning af angreb og drab på civile, så undergraver den udvikling regeringens legitimitet, og det samme gælder for regeringens sikkerhedsstyrker og udenlandske partnere. Målrettede mord på centrale embedsmænd og politiske ledere er også taget til. Fra januar til april 2012 blev begået 255 af den slags mord, en stigning på 53 pct. i forhold til samme periode i 2011. Slutresultatet er en atmosfære gennemsyret af frygt og usikkerhed. Kun få afghanere tror på, at ANSF vil være i stand til at beskytte deres liv og landets sikkerhed efter 2104.

Med sikkerheden som afgørende for den planlagte overdragelse fra internationale til afghanske styrker i slutningen af 2014 er det tvivlsomt, om præsident Hamid Karzais regering vil være i stand til at inddæmme truslen og stabilisere landet op til exitdatoen. Det ser tværtimod ud til, at oprørerne er fast besluttet på at presse massivt på for med støtte fra pakistanske allierede at vinde mere fodfæste før december 2014.

Dermed være ikke sagt, at alle oprørsfraktioner er forenede eller bliver ved med at være det. Især i takt med at den udenlandske tilbagetrækning nærmer sig, vil de enkelte fraktioner søge at tilkæmpe sig mak- 
simale fordele i enhver fremtidig forhandling. Uenighederne mellem de tre stærkeste oprørsgrupper Mullah Omars Quetta shura, Gubuddin Hekmatyars Hizb-e Islami og Haqqani-netværket - kunne udnyttes til at svække oppositionen, men Karzais skrøbelige regering mangler den politiske vilje samt kapaciteten og legitimiteten til at gøre det.

\section{Valgsvindel og blancochecks}

Valg kunne i et land uden repræsentative institutioner have hjulpet med at stabilisere det politiske liv, men i stedet valgte Kabul valgsvindel. I 2004 og 2005 satte afghanere sig modigt op imod oprørsvold for at bruge deres stemmeret. De valgte for første gang i landets historie en præsident og et parlament. Det svindelagtige præsidentvalg i 2009 og parlamentsvalg i 2010 har siden ødelagt afghanernes tillid til stemmeurnerne. Og mens valgsvindel har undergravet Karzai-regeringens legitimitet, ser afghanerne det internationale samfund som ansvarligt for ikke at have kaldt Kabul til orden.

Karzais regering har ikke brugt mulighederne ved den internationale sikkerhedstilstedeværelse og milliarder af dollar i international bistand til at skabe institutioner, der kan sørge for folks mest basale behov. I dag senere betaler den prisen i den klare mangel på legitimitet og folkelig støtte. Men det internationale samfund er også ansvarligt for at have forsømt at skabe en bæredygtig udvikling og for at give Kabul blancochecks. Denne mangel på overvågning er i vidt omfang ansvarlig for den korruption, der gennemsyrer statsinstitutionerne.

$\mathrm{Nu}$ forsøger donorlandene at gøre noget ved korruptionen. Af de milliarder, som blev lovet på konferencen i Tokyo over de næste fire år, er 20 pct. betinget af, at korruptionen reduceres. Det ser tvivlsomt ud. Og motiveret af hjemlige bekymringer især for vestlige økonomier vil hjælpen måske blive reduceret, og korruptionen brugt som retfærdiggørelse heraf, trods løfterne om robust $\varnothing$ konomisk støtte.

Kabul er heller ikke eneansvarlig for ikke at have brugt den udenlandske støtte effektivt. For eksempel viste en amerikansk rapport i juli 2012, at hundreder af millioner dollar er brugt på byggeprojekter, som har ringe chancer for at blive afsluttet, før udenlandske styrker trækkes tilbage. Derefter vil Kabul ikke have kapaciteten eller pengene til at videreføre mange af projekterne. Desuden vil det i takt med tilbagetrækningen blive stadig vanskeligere at bruge udviklingsbistanden, når flere områder falder til oprørerne, og ANSF ude af stand til at trænge dem tilbage.

Det internationale samfund har i årevis troet på, at militærmagt kan stabilisere landet. Men en sammenhængende indsats imod oprørerne ville have været mere effektiv til sta- 
bilisering. Militæroperationer, der tog sigte på at inddæmme oprøret, mens statsinstitutioner blev opbygget eller reformeret, ville have givet mere sikkerhed.

Når det gælder regeringsudøvelse er listen over, hvad Kabul burde gøre med støtte fra internationale partnere endeløs, men tre faktorer er særligt vigtige, som exit-dagen rykker nærmere: styrkelse af parlamentet, styrkelse af retssikkerheden og en valgreform. Hvis parlamentet havde kontrol med den udøvende magt, kunne det muligvis bremse noget af det værste magtmisbrug. At styrke valginstitutionerne kan sikre, at præsidentvalget i 2014 bidrager til intern stabilitet. Et fungerende retssystem og styrkelse af retssikkerheden er afgørende for enhver form for bæredygtig fred. På længere sigt er der behov for decentralisering af magten og ressourcerne, som i sig selv ville stabilisere dette multiregionale og multietniske land.

USA og dets partnere forpligtede på NATO-topmødet i Chicago i maj 2012 NATO til at støtte Afghanistans sociale og økonomiske udvikling og beskytte den forfatningsmæssige orden. Hvis de løfter er mere end floskler, kan det skabe en win-win situation for post-transition Afghanistan.

Ifølge NATOs oprindelige overgangsplan skulle den afghanske regering være fuld ansvarlig for sikkerheden ved udgangen af 2014. Målet for afghanske styrkers overtagelse af kampledelsen er nu ændret til slutningen af 2013. NATOs mission vil ifølge generalsekretær Rasmussen ændres til "rådgivning, træning og assistance til afghanske styrker efter 2014". Det accelererede tempo er imidlertid problematisk, da ANSF selv ved den oprindelige 2014 deadline vil være ude af stand til at dæmme op for oprørstruslen.

\section{ANSF og stabilitet}

I oktober 2012 var ANSF ifølge ISAF-chefen, general John Allen, $\emptyset$ verste ansvarlige for sikkerheden i 75 pct. af landet. Men mens overdragelsen af militær kontrol skrider frem, er der alvorlig tvivl om ANA's (Afghanistans Nationale Hær) og ANP's (Afghanistans Nationale Politik) kapacitet til i mangel af robust international støtte effektivt at overtage den operationelle kommando, når det gælder udstyr, kvalitet, træning og erfaring. Det amerikanske forsvarsministeriums generalinspektorat rapporterede i slutning af april, at kun syv pct. (15 ud af 219) ANA-enheder og kun ni pct. ANPenheder (39 ud af 435) kunne operere alene, selv med rådgiverbistand.

Selv om ANSF har modtaget over halvdelen af den samlede internationale hjælp til Afghanistan, har ANSF hidtil vist sig ude af stand til at håndhæve loven og modstå oprør eller, med enkelte undtagelser, blot sikre regionerne, hvor overgangen allerede har fundet sted. I Warkak provin- 
sen for eksempel, hvor de nu er uden international taktisk og logistisk støtte, har afghanske soldater ikke kunnet holde stand imod oprørere. I Helmand og også i Kandahar, hvor de forøgede amerikanske styrker angiveligt har trængt oprørerne ud, er de dukket op igen og kan potentielt genvinde al tabt terræn, når internationale styrker er trukket helt ud.

Den eneste bæredygtige strategi for tilbagetrækning, som kan sikre stabiliseringsprocessen, er givetvis, at ANSF erstatter internationale styrker. Men hæren, der er splittet etnisk og politisk, er langt fra parat til at tage den operationelle kommando, når det gælder udstyr, træning og erfaring. Selv om ANP og ikke ANA var det mest passende instrument til af slå oprøret ned, er det hæren, som får hovedparten af ressourcerne, og en dårligt udstyret og dårligt trænet politistyrke er ude af stand til at forsvare loven. Det er endnu værre, at uden politireform og på trods af international overvågning, er ANP en korrupt og grisk styrke, som de fleste borgere ser mere som en trussel end som en kilde til beskyttelse.

ANSF vil ikke blive i stand til at stabilisere eller beskytte landet inden for de næste to år, med mindre der sker en fundamental gentænkning af internationale strategier, hvilket synes stadig mere utænkeligt ud. Tværtimod indebærer det stadig større risiko, især hvis forslag om at skære ned på ANSF, der oprindeligt skulle være 352.000 , til muligvis 228.500 vedtages. Med mindre det forinden er gennemtænkt, hvordan demobiliseringen gennemføres, er der risiko for, at i tusinder af hjemsendte bevæbnede og trænede mænd vil tilslutte sig militser, kriminelle bander og/eller oprørere.

Beslutningen om at skabe og støtte Afghanistans Lokale Politi (ALP) har også vist sig modproduktiv. Mens noget af ALP's mandskab anklages for magtmisbrug, sympatiserer mange andre af dem med oprørerne. I september 2012 resulterede bekymringer for deres loyalitet $i$, at træning af og rekruttering til ALP blev suspenderet. Men selv hvis denne parallelle politistyrke opløses, vil Kabul drevet af politiske behov nok blive ved med at støtte militser, som meget ligner ALP.

Den hurtige og for tidligere internationale tilbagetrækning skaber andre farer for afghansk stabilitet.

Mens 'grønne mod blå' angreb fortsætter, vil stadig færre støtte bevarelse af rådgivere og trænere i landet efter tilbagetrækningen. Og det er netop formålet med de angreb. Så tidligt som i maj 2011 hed det i et studium fra den amerikanske hær, at de angreb "skabte en tillidskrise om vestlig træning af og samarbejde med ANSF". Situationen er meget værre nu. Mens internationale styrker fortsætter træning og vejledning i mindre omfang, vil deres behov for luftbeskyttelse formentlig stige med 
fare for at øge risikoen for civile drab. Det vil ikke blot styrke oprørernes propaganda og rekruttering, men også øge spændingerne mellem Kabul og dets vestlige allierede.

Endelig vil den amerikanske mission efter overgangen skifte til et snævert anti-terror fokus, med bevarelse af muligvis 10.000-20.000 soldater, overvejende specialstyrker, antiterror styrker sammen med noget træningspersonel. Denne fokus på terrorbekæmpelse vil uundgåeligt øge USA's afhængighed af korrupte og griske lokale ledere og bidrage yderligere til lokal desillusionering og usikkerhed, som er frugtbar jord for rekruttering og støtte til oprørere.

\section{Pakistan-faktoren}

Afghanistans sikkerhed afhænger lige så meget af, hvordan den internationale tilbagetrækning finder sted som af Pakistans rolle i at afgøre, om Afghanistan under og efter overgangen stabiliseres eller styrtes ned i kaos. Mullah Omars Quetta shura, Hekmayars Hizb-e Islami og Haqqani-netværket har ophold i Pakistan, der fungerer som afskydningsrampe for angreb på afghanske og internationale styrker. I oktober 2012 sagde ISAF-chefen general Allen: "Omar bor i Pakistan som mange af hans kommandører. Fra det sikre punkt har de sendt hundreder af letpåvirkelige overvejende religiøse unge i døden eller fængsel i Afghanistan".
Oprørets intensivering hænger sammen med disse fristeder på den anden side af grænsen. Hvis det var blevet nægtet disse grænseoverskridende fristeder at rekruttere, samle økonomiske midler og våben samt træne og planlægge, ville de internationale og afghanske styrker have haft langt lettere ved at gøre op med volden. Den stabilitet, der var kommet ud af det, ville meget bedre have fremmet etablering af et fungerende statsapparat og genopbygning.

Fortsat støtte fra Pakistans militær til afghanske oprørere vil uundgåeligt destabilisere Afghanistan. Ironisk nok har de afghanske oprørere, der støttes af pakistansk militær især Haqqani-netværket, tætte forbindelser med mange pakistanske militser, der kalder sig Pakistansk Taleban. Efter at de har rettet opmærksomheden indad, er deres paraplyorganisation Tehrik-e-Taliban Pakistan (TPP-Taliban Movement of Pakistan) nu en af de største trusler imod Pakistans sikkerhed. De oprørere bruger nu baser i Afghanistan, især i Kunar og Nuristan provinserne, til at angribe pakistanske grænseregioner. Den civile regering indser, at dens legitimitet afhænger af effektiv aktion imod terrornetværkerne, der er ansvarlige for drab på omkring 40.000 civile og over 5.000 sikkerhedsfolk siden 2002. Med de militante aktive over hele landet har den offentlige opinion nu vendt sig imod disse voldelige ekstremister.

Men militærets ledelse fortsætter 
med at skelne imellem gode og onde jihadister, hvor de sidstnævnte er dets stedfortrædere i Afghanistan og Indien. Det kan i sig selv ødelægge det internationale samfunds vigtigste mål i Afghanistan - at slå al-Qaeda - som USA's forsvarsminister, Leon Panetta, definerede som alQaedas vanskelighed ved at rekruttere nye folk. Pakistans militærs afghanske stedfortrædere som Haqqani-netværket har tætte bånd til og er afhængige af al-Qaeda, der er forbundet med pakistanske jihad-grupper som Lashkar-e-Tayyaba, der var ansvarlig for terrorangrebene $\mathrm{i}$ Mumbai i 2008. Det er på tide, at USA og dets allierede forstår vigtigheden af at etablere en sammenhængende politik imod denne Pakistan-baserede trussel. Specielt i den afghanske kontekst er det afgørende at forstå, at der ikke vil blive fred, før de pakistanske sikre baser er eliminerede.

\section{En forhandlet fred}

Det er lige så vigtigt at forstå, at de hjemlige imperativer i Afghanistan kan torpedere eller stabilisere posttransitionstaten. For mange internationale aktører og afgjort for afghanerne ligger nøglen til en vellykket overgang i succes eller nederlag i forsøgene på at forhandle en bæredygtig fred med oprørerne. Men endnu vigtigere er, hvordan sådanne forhandlinger foregår og indholdet af en eventuel aftale. Perspekti- vet for en forhandlet løsning før udgangen af 2014 er fjernt, og selv om sådan en aftale opnås, er det usandsynligt, at den overlever de udenlandske styrkers afrejse. Tværtimod vil enhver hastig aftale eskalere snarere end at reducere konflikten.

Et kritisk aspekt ved en bæredygtig forhandlingsproces er hjemlig legitimitet og handlemuligheder. Enhver forhandling må være helt og holdent afghansk ledet og inkluderende. Den må inkludere alle centrale afghanske politisk-etniske fraktioner, tadsjikerne, hazaraerne og usbekerne, så vel som alle dele af det pashtunske lederskab i processen. Bredere konsultationer må også inkludere Afghanistans civile samfund og især parlamentet. Mens det internationale samfund kan facilitere processen, vil knald eller fald for en sådan bestræbelse afhænge af $\mathrm{i}$ hvilket omfang der er bred afghansk støtte.

Hvis en aftale indgås i hast uden konsultationer med eller støtte fra alle interessenter, kan den lede til udbredt afhopning af folk, der venter på sidelinjen, til Taleban i det pashtunske syd og øst. Det ville betyde, at ikke-pashtuner standser al støtte til en regering og dens internationale partnere, som gør sikkerheden for deres samfund til gidsler for deres kortsigtede formål.

Den pakistanske faktor vil også her spille en vigtig rolle. Mens Pakistan må bringes ombord, må det ikke ske på bekostning af afghansk 
stabilitet. Pakistans militær må ikke få lov til at kapre processen til fordel for dets udvalgte afghanske stedfortrædere. For øjeblikket er der ikke meget, som tyder på, at Pakistans militær vil acceptere en løsning, som vil være acceptabel for de fleste afghanere, især de etniske minoriteter, selv om den eventuelt skulle være acceptabel for Kabuls internationale partner. Den pakistanske forsvarskommando vil i fravær af et samlet internationalt pres fortsætte med at støtte islamistiske pashtunske stedfortrædere for at styrke deres position i eventuelle forhandlinger med det formål at gøre dem til den dominerende faktor i Kabul.

Det pakistanske militærs dobbeltspil som partner for USA imod terrorisme samtidig med at det støtter voldelige ekstremister - pakistanske som afghanske - vil først slutte, når Washington sætter helt klare grænser og viser politisk vilje til at fastholde dem.

I juli 2012 kategoriserede Obamaadministrationen Haqqani-netværket som en 'udenlandsk terrororganisation'. Det var et lovende første skridt imod de elementer, der udgør den største fare for Afghanistans stabilitet efter 2014. USA og dets vestli- ge allierede må også sende klare og utvetydige signaler til Pakistans militær om at stoppe støtten til afghanske oprørere, ikke kun Haqqani-netværket, men også Hizb og Quetta shuraen, hvis opstandens vækst skal holdes i ave og oprørerne tvinges til forhandlingsbordet. Pakistans militær må også presses til at gøre en ende på støtten til afghanske oprøreres lokale allierede, herunder Pakistans Taleban-fraktioner, som militæret har indgået fredsaftaler med.

Frem for alt må det internationale samfund ikke koble tidsrammen for sikkerhedsovergangen sammen med tidsrammen for en politisk løsning med oprørerne. Det bør i stedet fokusere på at sikre en stabil politisk transition. En udøvende afghansk magt og et parlament, der etableres ved frie og fair valg, vil have mere troværdighed og legitimitet til at forhandle med oprørere og - endnu vigtigere - have evnen til at stabilisere et skrøbeligt samfund.

Samina Ahmed er projektdirektør for Sydasien i International Crisis Group (ICG). Denne artikel er hendes personlige analyse og ikke nødvendigvis ICG's.

(Oversat fra engelsk af Vibeke Sperling) 